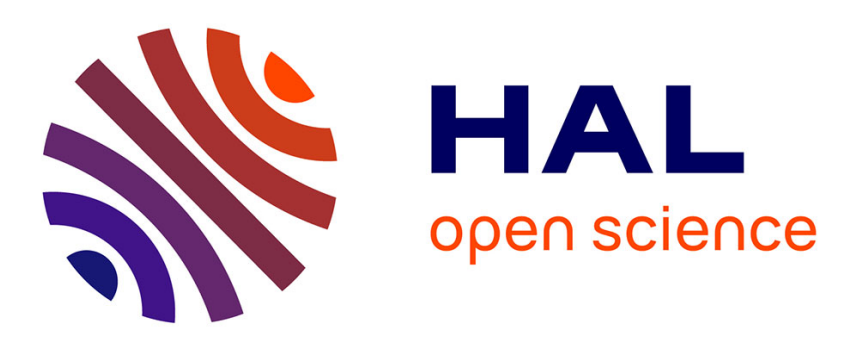

\title{
Study of native starch hydration : influence of sorption hysteresis
}

\author{
Herve Bizot, Alain Buleon, N. Riou
}

\section{To cite this version:}

Herve Bizot, Alain Buleon, N. Riou. Study of native starch hydration : influence of sorption hysteresis. Journal de Physique IV Proceedings, 1984, 45, pp.259-264. hal-02724364

\section{HAL Id: hal-02724364 \\ https://hal.inrae.fr/hal-02724364}

Submitted on 2 Jun 2020

HAL is a multi-disciplinary open access archive for the deposit and dissemination of scientific research documents, whether they are published or not. The documents may come from teaching and research institutions in France or abroad, or from public or private research centers.
L'archive ouverte pluridisciplinaire HAL, est destinée au dépôt et à la diffusion de documents scientifiques de niveau recherche, publiés ou non, émanant des établissements d'enseignement et de recherche français ou étrangers, des laboratoires publics ou privés. 
H. Bizot, A. Buleon and N. Riou

INRA - LSCDA, Rue de la Geraudière, 44072 Nantes Cedex, France

Résumé : L'étude de la sorption de l'amidon de pomme de terre à l'état natif granulaîre présente des particularitês structurales (évaluation de la cristali inité apparente dêcelée par diffraction $X$ ) et thermodynamique (important phénomẽne d'hystérêsis en l'absence de porositê). Les rêsultats présentés ne permettent pas encore une synthèse explicative mais les ètats obtenus en désorption résultent probablement de faux équilibre à dêrive très lente.

Abstract : Results concerning water sorption in native potato starch granules are presented for structural properties (evolution of apparent X-ray crys= tallinity with water uptake) and for thermodynamical data (large hysteres is phenomenon in the absence of definite porosity). A synthetic explanation is not yet possible but the desorption pseudo equilibria observed are probably transitory states drifting very slowly.

Starch is the most important photosynthetized polysaccharide after cellulose in nature. It is the main reserve substance for a lot of higher plants and an energy source for many organisms, from bacteria and molds to the higher animals and man. Starch is mainly extracted from maize and potatoes and used essentially for food purposes $(50 \%)$ or other numerous industrial processings such as adhesives, coating, floculating, chemicals and building materials.

Starch granules (20 to $80 \% \mu$ in diameter) are complex architectures of concentric shells with radial orientations and can have very different shapes from the nearly perfect sphere (wheat) to the polyhedral granules in rice. They are constituted of two macromolecules, in the case of potato, the linear poly $x[1 \rightarrow 4] \quad D$ anhydroglucose $(P D \simeq 400)$ called "amylose" represents about $20 \%$ of the dry matter ; the rest is made of large branched "amylopectin" molecules (PD $10^{5}$ to $\left.10^{9}\right)$ in which side chains are grafted about every 20 residues by $\alpha[1 \rightarrow 6]$ bounds to form a tree like arrangement. Linear segments have a natural tendency to take a helical conformation.

With regard to its hydration properties, starch can be considered as a thermo-hydro plastic material (melting at $60^{\circ} \mathrm{C}$ when saturated by water : gelatinization). Although $30 \%$ appear to be crystalline, giving clear X-ray diffraction diagrams essentially when hydrated, all hydroxyls are fulty exchangeable as observed with NMR. The saturation $\left(54 \% \mathrm{H}_{2} \mathrm{O}\right.$ d.b.) would correspond to only 5 water molecules per anhydroglucose cycle ( 3 free $\mathrm{OH}$ groups, if these were all fully available) while nitrogen surface area is only $0,2 \mathrm{~m} 2 / \mathrm{g}$ after drying. The sorption-of water molecules modifies interhelical bonds and the structural fiuctuations are likely to be accompanied by strain accumulation and relaxation. Many reviews have been made on the physical, biochemical and chemical properties of starches, the most recent are those of FRENCH, 1984, GUILBOT and MERCIER, 1984 and VAN DEN $B E \bar{R} \bar{G}, 1981$. This short paper reviews our contribution to the hydration behaviour of native potato starch and particularly hysteres is (BIZOT and Coll., 1984).

I - CHARACTERISTICS OF SORPTION EQUILIBRIA and its influence on structural and volumic properties

After complete drying at $130^{\circ} \mathrm{C}$ for $1 \mathrm{H} 30$ or by vacuum drying at $50^{\circ} \mathrm{C}$ (MULTON and Col1., 1980) the equilibration requires one day to a week, the initial 
Fickian phase is followed by a relaxational lagging period. The sorption isotherms obtained by plotting the water content versus the water activity $\left(a_{w}=\frac{\hat{P}_{W}}{P_{O W}}\right)$ of equîjibration are well described by the Guggenheim-Anderson-De Boer model which is a generalization of BET :

$$
\frac{w}{W m}=\frac{C k A_{w}}{\left(1-K a_{w}\right)\left(1-K a_{w}+C k A_{w}\right)}
$$

with :

Aw Water activity

W Water content on dry bas is

Wm Water content corresponding to saturation of all primary adsorption sites by

c Guggenheim's constant : $c=c^{\prime}$ '

Hq Total heat constant : $\mathrm{C}=\mathrm{C}$ exp $\left(\mathrm{H}_{\mathrm{m}}-\mathrm{H}_{\mathrm{a}}\right) / \mathrm{RT}$ pure water $\mathrm{H} 1$

$\mathrm{Hm}$ Total heat of sorption of the first layer on primary sites

$k$ Factor correcting properties of the multilayer molecules with respect to the bulk liquid ( $\left.K=K^{\prime} \exp (H 1-H q) / R T\right)$

see VAN DEN BERG (1981) and BIZOT H. (1983) for details.

Adsorption and desorption isotherms for potato starch are presented on the figure 1 with the values obtained by a quadratic regression for $W m, K$ and $C$ and the RMS $\%$. This latter quantifies the fitting quality between experimental points and
"GAB" model.

\begin{tabular}{|c|c|c|}
\hline \multicolumn{3}{|c|}{ Guggenheim regression coefficients } \\
\hline & RES & DES \\
\hline$w_{m}$ & 9.979 & 13.637 \\
\hline K & 0,729 & 0,687 \\
\hline C & 26.371 & 15.972 \\
\hline RMS \% & 3.9 & 5.0 \\
\hline
\end{tabular}

FIGURE 1. DESORPTION-RESORPTION SCANNING CURVES AT $25^{\circ} \mathrm{C}$

(*: Reversal point; $A w=\frac{P_{W}}{P_{0} W}$ )

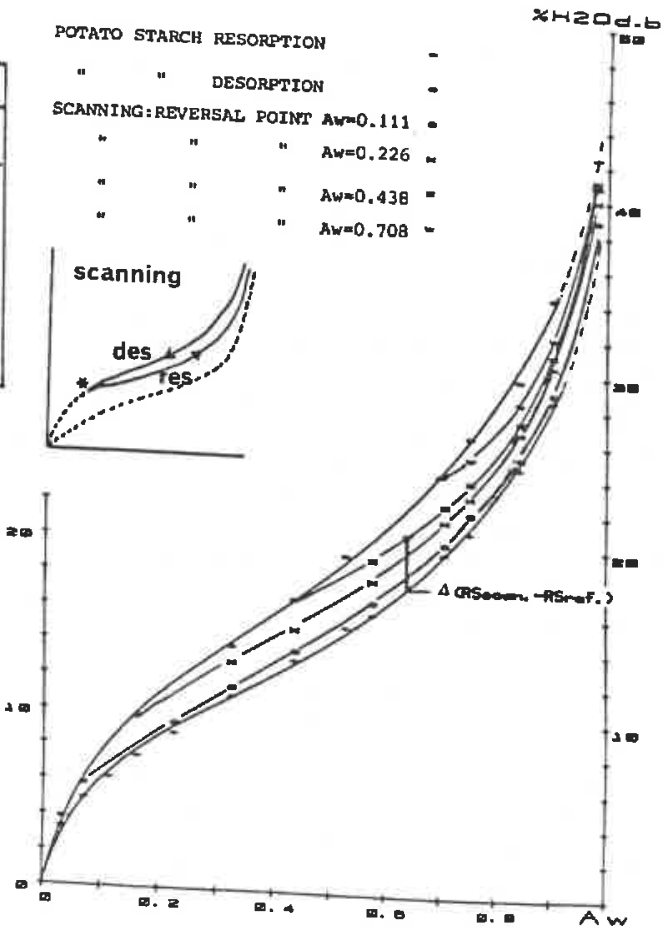

This sho BERG (19: differenc of swe 771 wing EVE during a

$$
-\frac{\Delta w}{T}
$$

In and grapl

A strong

ture is.n even afte an exothe The water con gral in 0 to be muc versal wa

Clapeyron been eval 
A strong hysteresis is visible on the whole water activity range and amounts to about $30 \%$ of the water sorption capacity up to $A w=0,8$. The granular architecture is not compulsary for hysteres is to develop since it is partially retained even after gelatinization (BIZOT et al., 1984). The sorption capacity and hysteresis

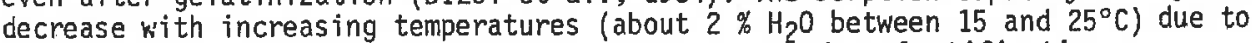
an exothermic excess heat of sorption and a progressive plastification.

The desorption is not uniquely defined and depends on (i) the number of successive cyclings (first desorption from fresh patato starch has $1 \%$ higher water content); ( $i i)$ the equilibration mode (interval in multiple steps or integral in one step which gives lower values); (iii) the local fluctuations which favour relaxation and lead to a drift toward resorption. The resorption appears to be much more reproducible but intermediate scanning curves depend on the reversal water activities which influence sorption up to saturation.

\section{II - THERMODYNAMICAL EVALUATIONS}

In order to compare with differential isosteric heats calculated by ClausiusClapeyron formulation (LE MAGUER, 1984); the integral heats of sorption have been evaluated from calorimetric wetting experiments (Figure 2)

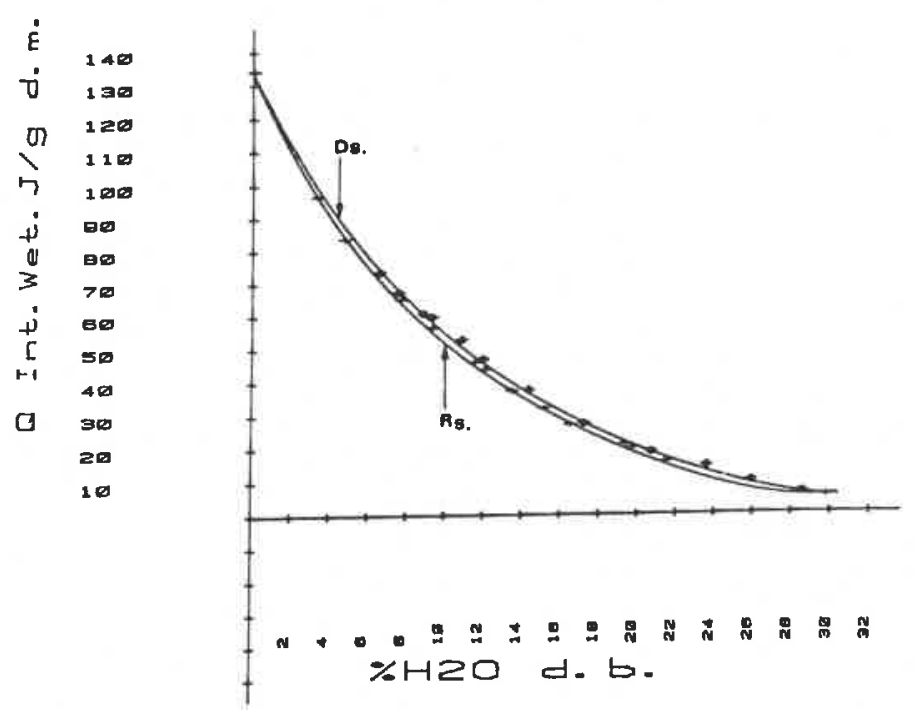

FIGURE 2, EVOLUTION OF INTEGRAL HEAT OF WETIING HITH WATER CONTENT AND HYSTERESIS

This shows a slight hysteresis on the whole range as observed also by VAN DEN BERG (1976). The desorption heats of wetting are higher than in resorption, this difference may be attributed to an endothermic term corresponding to the energy of swelling. An attempt to quantify hysteresis is presented on figure 3 . Following EVERETT's proposal (1955) the work of compression done by the surrounding during a closed cycle is identified with the irreversible entropy production.

$$
-\frac{\Delta w}{T}=\Delta \operatorname{sirr}=R \quad \oint n^{w} d i n \text { Aw }
$$

Integrating this expression using GAB formula on the main hysteres is 1oop and graphical integration for partial scanning cycles, it was possible to compare 
the irreversible entropy production for each scanning loops. Considering only the orders of magnitude, the more regular swelling is associated with a rather linear evolution of irreversible entropy while desorption-resorption scannings present an inflexion point around $9 \% \mathrm{H}_{2} \mathrm{O} \mathrm{d} . \mathrm{b}$. This may be related to a change in collap1981).

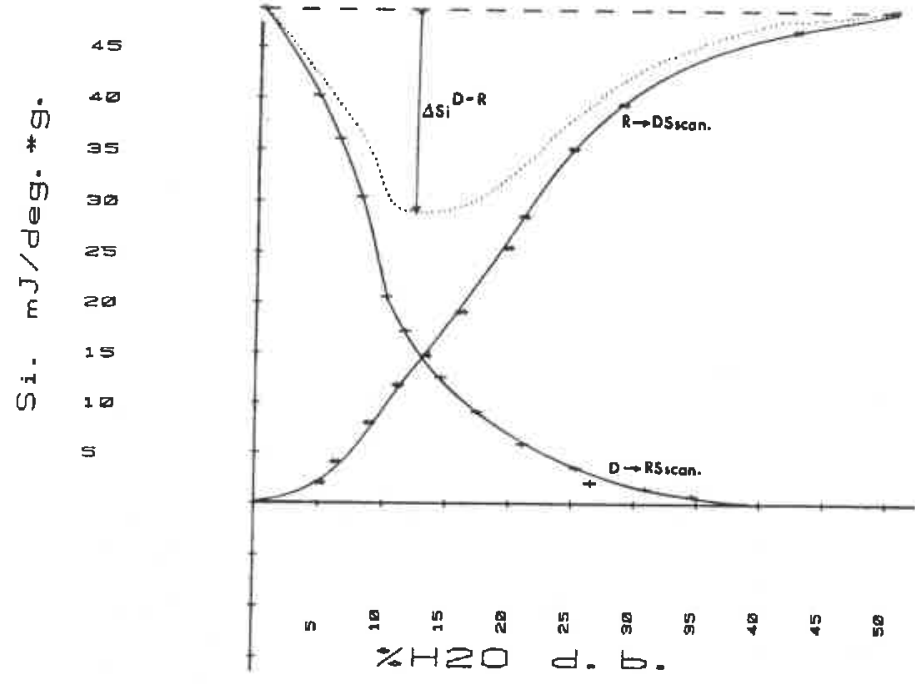

III -

$x$-ray

B typ

gemen

diagr

have

fiber

of am

solve

effec

sharp

SARKO

to th

peaks

whole

ceabl

sorpt

puzz 1

$121 \mathrm{r}$

figur

FIGURE 3. IRREVERSIBLE ENTROPY PRODUCTION CALCULATED FROM SCANNING CURVES DATA USING FORMULA 2

The notion of swelling is not easily clarified by specific volume measurements using toluene immersion picnometry at different states of hydrations (Figure 4). Hysteresis is only apparent under $10 \% \mathrm{~d} . \mathrm{b}$. in the least ideal range, while water and starch volumes become additive only above $33 \% \mathrm{H}_{2} \mathrm{O} \mathrm{d}$.b. (V. HAINE,
1984 ).

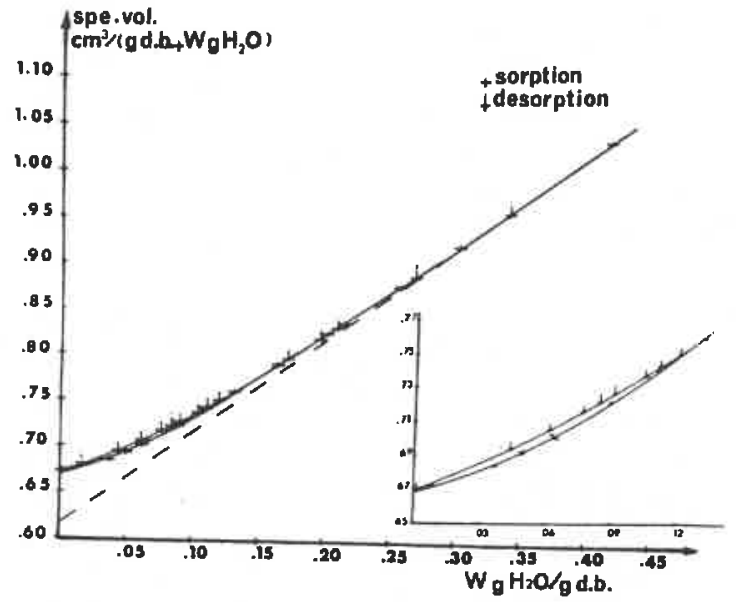

FIGURE 4 EVOLUTION OF lg ORY STARCH SPECIFIC VOLUME WITH HYDRATION AND HYSTERESIS. 


\section{III - STRUCTURAL ASPECTS}

Starches can be classified in two main structural types following their $X$-ray diffraction diagrams : the A type characteristic of cereal starches and the $B$ type of tuber starches. Due to the complexity of the cristallographic arrangements of the chains in the starch granule and the poor quality of X-ray powder diagrams the crystalline organization of starch is not we 11 known. Several models have been used to approach the structure of crystalline parts of granule, amylose fibers (WU and SARKO, 1978) hydrolyzed starches (CLEVEN, 1978) or single crystal of amylose (BULEON et a1., 1984), but important inconsistancies are still unresolved. Water is necessary to the crystalline organization of the granules, this effect being especially remarkable for the $B$ type as shown on Fig. 5 , where the sharpest diagram $\left(33 \% \mathrm{H}_{2} \mathrm{O}\right)$ is indexed following the unit cell system of $W U$ and SARKO (1978). The intensity of the 100 reflexion $\left(2 \theta=5,6^{\circ}\right)$ which corresponds to the interhelical distance increases very strongly with water uptake. The other peaks of the diffraction diagram become also sharper with hydration, along the whole adsorption range (BULEON et al., 1982). A "structural hysteresis" is noticeable since starch, for a same water content, seems to be more crystalline in desorption than in adsorption. The non identity with the volumic hysteresis remains puzzling. This behaviour is illustrated by the respective evolution of 100 and 121 reflexions intensities with water content in adsorption and desorption on figures 6 and 7 .

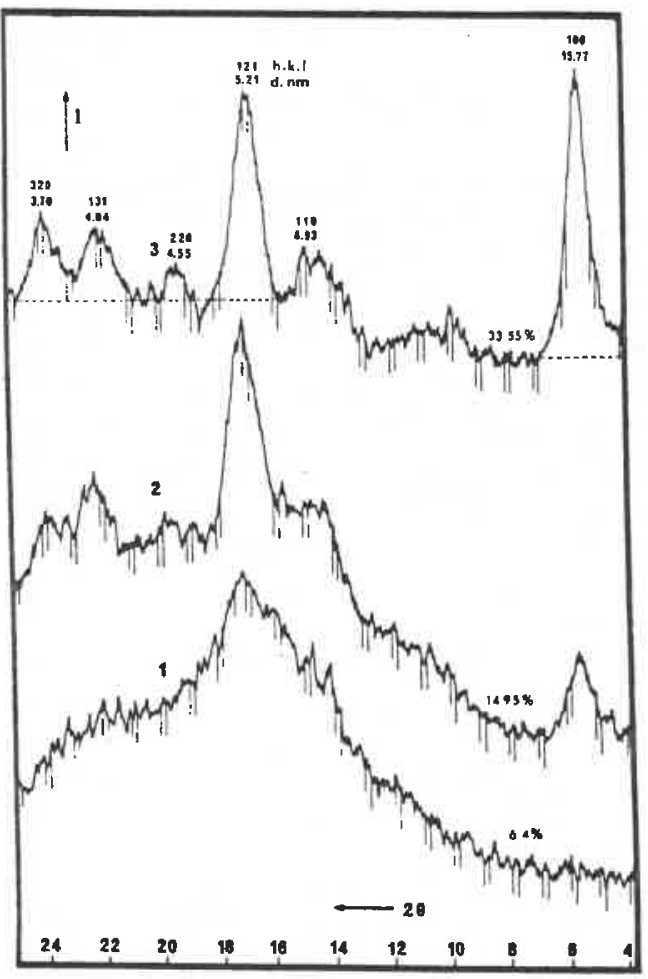

Figure 5 . Development of $X$-ray diffraction pattern with hydration.

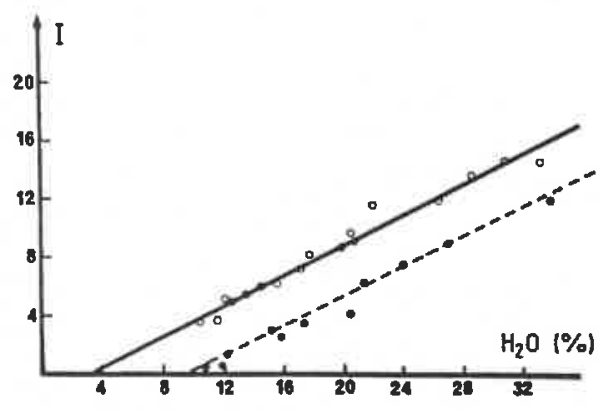

Figure 6. Evolution of (100) reflexion intensity with water content in adsorption and desorption; $\mathrm{I}_{100}=\mathrm{l}\left(\mathrm{H}_{2} \mathrm{O} \%\right)$ : $0-\mathrm{O}=$ desorption. - - $=$ sorption.

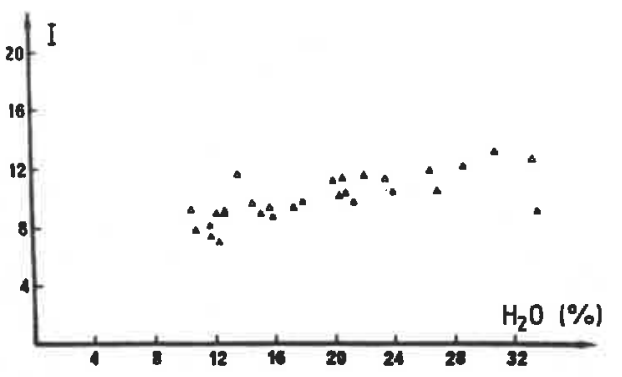

Figure 7. Evolution of (121) reflexion intensity with water content in adsorption and desorption; $l_{\mid 21}=\left\{\left(\mathrm{H}_{2} \mathrm{O} \%\right) ; \Delta=\right.$ desorption. = sorption. 


\section{CONCLUSION}

Research advances about water interaction of starch have not been progressing as fast as for wool keratin or cellulose probably because fewer technological applications are involved on an industrial scale but also because the product itself is complex. Up to now, microscopic examinations, enzymic degradation, sorption and calorimetric measurements and $X$-ray diffraction analysis have not been sufficient to give a satisfactory representation of the granular structure with the repartition of cristalline and amorphous regions.

In connection with the analysis of sorption hysteresis on non porous media the swelling, relaxation and plastification of starch matrix needs to be better quantified on an energetic and time scale. At the moment practical applications of theses studies are directed toward granular starch accessibility in the liquid phase following different solvent sequences. Potential applications concern nutritional aspects, as well as aroma retention and modified starch technology.

\section{REFERENCES}

BIZOT H. (1983) - In "Physical properties of Foods" JOWITT R. and Coll Ed. Applied Science Publishers. pp 43-54.

BIZOT H., BULEON A., MOUHOUS-RIOU N. and MULTON J.L. (1984) - In "Influence of water on Food Quality and Stability".

SIMATOS D. Ed., NIJHOFF M. Pub. The Hague, Netherlands. (to be published).

BULEON A., BIZOT H., DELAGE M.M. and MULTON J.L. (1982) - Die Stärke, 34, 11, pp 361-366.

BULEON A., DUPRAT F., BOOY F.P. and CHANZY H. (1984) - Carbohydrate Polymers, 4, pp 161-173.

CLEVEN R., VAN DEN BERG C. and VAN DER PLAS (1978) - Stärke, 30, 223.

EVERETT D.A. and WHITTON W.I. (1955) - Proc. Royal Soc. (London) A 230, pp 91-110.

FRENCH D. (1984) - Physical and chemical organization of starch granules. In "Starch : chemistry and Technology" 2 nd Ed. chap. 8.

WHISTLER R.L. PASCHALL E.F. and BEMILLER J.N. Eds., Academic Press.

GUILBOT A. and MERCIER C. (1984) - "Starch" in "The polysaccharides". ASPINAL G.0. Ed. Vol. 3. Academic Press. (to be published).

LE MAGUER M. (1984) - In "Influence of water on Food Quality and stability". SIMATOS D. Ed., NIJHOFF M. Pub. The Hague, Netherlands. (to be published).

VAN DEN BERG C. (1981) - "yapour Sorption equilibria and other water starch interactions ; a physicochemical approach", Diss. Wageningen.

WU H.H. and SARKO A. (1978) - Carbohydr. Research, 61-7. 